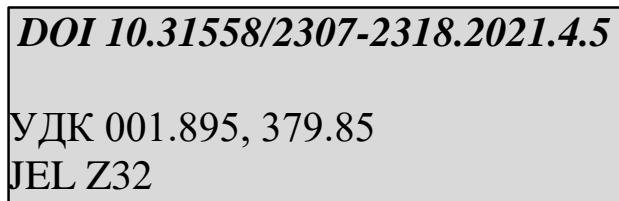

Корж Н. В.,

доктор економічних наук, професор, Вінницький торговельно-економічний інститут КНТЕУ, norischuk067@gmail.com ORCID ID 0000-0002-4901-3078

\title{
Онищук Н.В.,
}

кандидат економічних наук, доцент, Вінницький торговельно-економічний інститут КНТЕУ, onivin@ukr.net

ORCID ID 0000-0002-1635-0801

\section{ФАКТОРИ ІННОВАЦЙНОГО РОЗВИТКУ ТУРИСТИЧНИХ ДЕСТИНАЦИЙ}

У статті розглядається поняття «розумної» туристичної дестинації $i$ аналізуються типові особливості «розумної» дестинаиії $i$ «розумного» міста. На основі узагальнення передового зарубіжного досвіду розглянуті технологічні основи "розумного» туризму. Пропонується оригінальна модель основних чинників інноваційного розвитку туристських дестинацій. Обтрунтовано, щзо «розумний туризм» привносить додаткові сочіальні та економічні вигоди, сприяє підвищенню конкурентоспроможності високих технологій в туристичній сфері, оптимізує професійну структуру туризму і збагачує емоиіональний капітал туриста. Крім того, він формує попит, регулюе споживання між традиџійними $i$ інноваційними додатковими послугами.

Ключові слова: туризм, знання, емоційний капітал, SMART-критерії, розумний туризм, розумне місто.

Puc.1, Лim.11

Постановка проблеми. «Розумний» туризм - це концепція, яка за останні п’ять років стала популярною як в галузі, так і в академічних колах. Китай,Іспанія та Південна Корея запустили програми розвитку інтелектуального туризму, а Європейський Союз представила ініціативу «Європейська столиця розумного туризму» $[1,2,3]$. Поняття «розумної дестинації» в дослідженнях економіки туризму нерозривно пов'язане 3 поняттями «розумного міста», «розумної екосистеми» та їм подібним визначенням в суміжних областях наукового знання - від культурної антропології до екології людини, містобудування, мережевої архітектури та стратегічного менеджменту. Предикат «розумний» в застосуванні до речей, об'єктів, процесів і середовищі активності залежить від автоматизованих систем управління і передачі інформації та передбачає розвиток різних форм штучного інтелекту.

Дослідження концепту «розумна дестинація» пов'язують 3 поняттям «розумного міста», але не завжди розмежовують відмінності теоретичного і практичного порядку. Хоча два цих поняття взаємопов'язані, але в дослідженнях «розумного міста» мова йде про технологічне збагачення міського середовища людського проживання в широкому 
сенсі слова. Разом 3 тим, проблема «розумної дестинації» специфічна саме для економіки туризму і відображає проблему з боку споживчого попиту.

Підходи до проблематики «розумної» туристичної дестинації, які сьогодні існують можна поділити на дві групи: акцентування уваги на використанні «розумних» технологій в процесі маркетингу і споживання туристичних послуг, і використанні зручностей «розумного міста». Теоретико-методологічні орієнтації цих досліджень, відповідно, різні: в першому випадку аналіз ведеться з точки зору організації бізнесу, а в другому - охоплює аспекти енергозбереження та сталого розвитку, безбар'єрної системи існування, підтримки історично маргінальних субкультур і т. ін. [4].

Аналіз останніх досліджень і публікацій. «Розумний» (SMART) туризм отримав імпульс в дослідженнях, викликаних революцією в сфері інформаційних і комунікаційних технологій. Використання SMART технологій лежить в основі розробки стратегії розвитку територіальних громад, бізнес-сфери і супроводжується пошуком розумних пристроїв, послуг і туристичних напрямків. Однак досвіду як головному фокусу розвитку інтелектуальності в туризмі і дестинацій приділяється порівняно мало уваги. Інтелектуальні екосистеми, підтримувані конкретним географічним контекстом, сприяють спільному створенню багатого технологічного досвіду розумного туризму (STE), прецедентні конструкції якого складаються з:

а) спільного технологічного досвіду;

б) інтелектуальних напрямків.

Хоча інтерес до розвитку «розумного» туризму зростає та виходить за межі окремих інтелектуальних напрямків, проте сучасні дослідження і практика не надають йому концептуального визначення, яке могло сприяти розвитку «розумного» туризму на регіональному рівні. Проблемам розвитку SMART -туризму, SMART -дестинацій та їх складових присвячені праці Д. Бухаліса, А. Інверсіні, Р. Баггіо, К. Боеса тощо. Особливості формування та розвитку дестинацій досліджували такі вітчизняні науковці, як: А. Мазаракі, С. Мельниченко, Т. Ткаченко та інші.

Визначення питань, які не вирішені в даній для дослідження проблематиці. Однак, не обгрунтованим залишається принципова роль нових технологій у розвитку «розумного» туризму взагалі і «розумної» дестинації, зокрема; аналіз перспективних для розвитку туристичного бізнесу технологій 3 точки зору споживчої функціональності відповідних мобільних додатків (аплікацій).

Метою статті $\epsilon$ уточнення різниці між поняттями «розумна дестинація» $\mathrm{i}$ «розумне місто»; узагальнення кращих практик організації «розумних» туристичних дестинацій за кордоном; виявлення і класифікація чинників розвитку «розумних» дестинацій.

Виклад основного матеріалу. Термін «дестинація» 3 точки зору географії означає місце призначення, місце яке, туристи вибирають для відвідування. У документах Всесвітньої туристської організації ООН є таке трактування: «Дестинація визначається як місце, відвідування якого є центральним у вирішенні зробити поїздку» [1]. В економіці поняття дестинації виходить за рамки локації і включає мотивацію споживчого вибору, все те, що мотивованого потенційного туриста змушує здійснити подорож в дане місце. Для індустрії туризму дестинації $є$ комплексним комерційним продуктом. Цінність дестинації, як і будь-якого іншого пропонованого на ринку продукту, може збільшуватися за рахунок іiі інноваційного розвитку. Інновація в туризмі формує нову ринкову пропозицію, яка користується попитом, оскільки створює нову цінність для споживачів, задовольняє нові потреби туристів в якісно інший спосіб і з більшою задоволеністю. 
«Розумний» став новим терміном, щоб описати технологічний, економічний i соціальний розвиток, підтримуючі технології, великі бази даних, використання складної аналітики, моделювання, оптимізації та візуалізації для прийняття кращих рішень. Термін був доданий до міст («розумне» місто) і технологій (смартфон, смарткарта, Smart TV). У застосуванні до неживих предметів і цифрових процесів «розум» означає мультифункціональність і високі можливості з'єднання.

В контексті економічних систем, термін «розумна економіка» означає використання технологій, що підтримують нові форми співпраці та створення вартості, які сприяють інноваціям та забезпечують конкурентоспроможність.

Поняття «розумного» міста відноситься до спільного функціонування інформаційно-комунікаційних технологій, модернізованих технічних систем і розвиненої соціальної системи 3 метою підвищення якості життя громадян і зростання міських послуг [2]. «Розумне» місто можна визначити як вимірну, технічно пов'язану взаємопов'язану і інтелектуальну міську систему. «Вимірна система» означає, що іiі роботу можна виміряти кількісно за допомогою апаратури, сенсорів, датчиків. «Взаємопов'язана система» означає, що всі їі частини, підсистеми, елементи об'єднані мережами інформаційно-комунікаційних технологій (ІКТ). «Інтелектуальна система» відноситься до додатків, які дозволяють генерувати більш точні і ефективні рішення [3]. Місто може бути визначене як «розумне», якщо стале економічне зростання i висока якість життя досягнуті через інвестиції в людський капітал та інноваційну інфраструктуру [4]. Людський капітал тут є ключовим елементом. Інноваційний потенціал міста зростає на основі всебічного розвитку людського, соціального капіталів [3]. «Розумне» місто не є тільки результатом інноваційного процесу, але й само виступає інноваційною системою, яка підсилює співтворчість i співпрацю всіх стейкхолдерів з метою постійного поліпшення якості життя мешканців і заохочує їх до творчо-інноваційної діяльності.

У Європі «розумні» дестинації виростають 3 раніше реалізованих проектів «розумного» міста. Туристичні програми для мобільних телефонів використовують на основі використання баз даних, що подаються в новому ключі і для іншої аудиторії [9]. Так, наприклад, веб-сайти музеїв та концертних залів, як і інформація про культурнорозважальні заходи на сезон, переводять на іноземні мови, пакетують в форматі єдиного додатка, рекламують на веб-сайтах туристичних операторів, міжнародних авіаліній, готельних консолідаторів.

«Розумні» міста Америки і Австралії акцентують увагу на управлінні, відкритості муніципальних служб, використанні новітніх технологій для оптимізації транспортного забезпечення, водопостачання, міської електромережі, паркувальних майданчиків, нічного освітлення і т.ін. У Нью-Йорку міські таксофони замінюють на безкоштовні станції Wi-Fi, Інтернету. У Канзас-Сіті і Далласі міські ліхтарі оснащують датчиками руху, що дозволяють економити енергію. У Ванкувері встановлені на жвавих перехрестях вуличні камери відеоспостереження транслюють зображення онлайн, допомагаючи водієві вибрати не завантажений маршрут. Мобільна аплікація дозволяє зв'язатися терміново з міськими службами, викликати ремонтну бригаду, отримати інформацію про події в місті. Все це робить «розумні міста» зручними для проживання та відвідування [2].

Мета розвитку туризму в дестинації - центрах світового туризму, як правило, пов'язана не з зростанням туристичних потоків, а зі стійким розвитком туризму. Відомі дестинації потерпають від перевантаження на територію, комунальних служб i туристських об'єктів. Так, в 2016 р Відень приймав близько 6.9 мільйонів туристів, що 
виражається в 14,96 млн. ночей перебування і проведенні понад 3500 конгресів, займаючи за цим показником одне з провідних місць в світі [2]. Барселону відвідало 32 млн. чоловік при населенні в 1,6 млн. чоловік; Амстердам, 3 населенням 850 тис. чоловік, - 17 млн. туристів за рік. В історичному центрі Венеції мешкає 56 тис.чол., а за 2016 рік їі відвідали близько 25 млн. туристів з 52,7 млн. ночей перебування. Мекка

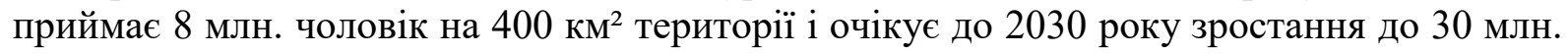
паломників [2].

Влада дестинацій, вирішуючи проблеми перевантаженості туристичними відвідинами посилюють розвиток інновацій, особливо в розрізі стратегічного розвитку «розумного міста». Так, Барселона в 2016 р була визнана «розумним» містом №1 в світі. За нею йдуть Нью-Йорк, Лондон, Ніцца, Сінгапур. Не тільки столиці, міста центри всесвітньої культурної спадщини, а й невеликі міста обирають стратегію формування розумної дестинації. Прикладом може бути Аліканте, що спеціалізується на гастрономічному туризмі [5].

У деяких країнах ініціативи зі створення «розумних» дестинацій поширюються зверху - владою на рівні регіону і країни. Цей тренд особливо простежується в Азії, де заохочення «розумного» набуває рис національної планової політики $[6,10,11]$. Йдеться передусім про створення насиченого довідково-інформаційного поля, забезпечення потреби туриста англійською або іншою доступною йому мовою в режимі реального часу. Технологічними проблемами у розвитку «розумного» сервісу залишаються універсальна доступність бездротового мобільного Інтернету, систем передачі даних BlueTooth, Wi-Fi i їм подібних, а також необхідних інформаційних матеріалів і додатків для мобільної телефонії: міні-атласів, туристських довідників, навігаційних програм, визначників маршруту, тематичних і колаборативних систем, тощо.

Ще у 2013p. Відень ініціював редакцію стратегії «Smart Мiсто Відень», зі збереження своїх ресурсів і підвищення якості життя в місті, що має бути досягнуто через всебічні інновації. На сайті агентства The Smart City Wien Agency, яке управляє впровадженням стратегії, розміщена інформація про проекти «Розумного міста», серед яких:

- Лейла Відень, «перша бібліотека речей», контактний центр економіки спільного споживання в Австрії;

- зелена архітектура і будівництво: «Зелені фасади Відня», вертикальні сади, «Погодний парк» для захисту від вітрів, мережа підземних колекторів для захисту спостережень; створення системи планування міського екологічного будівництва;

- енергоефективність;

- очищення повітря («ViennaGreenCO2») і води, переробка сміття;

- «розумна» міська логістика;

- co-Creation Lab для співпраці в розробці інноваційних рішень;

- розвиток цифрової економіки (додаток «Sag's Wien» для діалогу між громадянами та адміністрацією; додаток Wien.at live - корисна інформація про місто для смартфонів; «DigitalCityWien» для інформування про можливості інформаційних технологій і навчання фахівців);

- e-Health для поліпшення медичних послуг через інформаційно-комунікаційні технології: телемедицина, інструменти аналізу конфеденційних даних за станом здоров'я та ін.;

- SocialCityVienna - платформа для соціальних інновацій, консультаційний центр для мікропідприємств та індивідуальних підприємців; проект для волонтерів; відеокурси і тести для самоосвіти [6]. 
Щоб «розумне» місто стало «розумною» дестинацією необхідна розробка і впровадження технологічної платформи, через яку здійснюється зв'язок на ринку туризму і забезпечена доступність туристичної інформації. Впровадження власної платформи дестинації допомагає залучити туриста, поліпшити управління ресурсами, підвищити конкурентоспроможність дестинації і задоволеність туристів, забезпечити стійкий довгостроковий розвиток дестинації. Розвиток «розумної» дестинації зменшують технології хмарної комп'ютеризації (хмарні обчислення), Інтернет речей і система Інтернет-сервісу кінцевого користувача [7].

«Розумні дестинації» надають можливості цифрових послуг з метою залучення більшої кількості туристів та підвищення ступеня їх комфорту в місцях перебування. Кліентоцентричність є головною відмінною рисою «розумної дестинації». Отримана через мобільні додатки інформація - контекстуальна і специфічна, прив'язана до реального часу, прихильності, сезону, особливостям місця перебування туристського попиту і категорії туриста (індивідуальний мандрівник, сімейна група, тур-група, що подорожує по бізнесу, учасник професійної конференції і т.ін.). Орієнтовані на туриста мобільні додатки виконують послуги інтерактивного характеру там i тоді, де i коли вони потрібні. У той же час вони дозволяють мандрівникові негайно ділитися враженнями, підтримуючи свій статус і видимість в соціальних мережах.

Пов'язувати категорію «розумного» туризму лише з впровадженням технологій в туристичні пропозиції, чи як результат IT розробки, яка $\epsilon$ рушійною силою подальших інновацій в туризмі [8]. Це позиція електронного туризму, яка орієнтована на інформатизацію та віртуалізацію туристичних обмінів та використання цифрових ланцюгів створення вартості. В цій царині, Гретцель У. пов'язує «розумний» туризм 3 інтелектуальною цифровою екосистемою, яка сприяе інноваціям, основаних на даних, i підтримує нові бізнес-моделі. Вона визначає «розумний» туризм як: «туризм, який підтримується інтегрованими зусиллями в дестинації по збору та агрегуванню даних отриманих 3 фізичної інфраструктури соціальних мереж та владних структур в поєднанні з використанням передових технологій, щоб перетворити ці дані на ціннісну пропозицію, з чітким акцентом на ефективність, сталість та збагачення досвіду в дестинації [8].

«Розумний» (SMART) туризм слід розглядати як філософію його управління та стратегічного розвитку, оскільки туризм пов'язаний 3 фізичними атрибутами дестинації, іiі концептуалізацією як більшої екосистеми та залежністю від державноприватного партнерства. Таким чином, «розумний» туризм поєднує віртуальне і фізичне, охоплює більш широкі техно-утопічні уяви про напрямки i потребує серйозного управління. Крім того, електронний туризм охоплює всі етапи туристського досвіду (до, під час та після подорожі), а «розумний» туризм формує досвід під час подорожі. Відповідно, «розумний» туризм складається з п’яти рівнів:

1) фізичний рівень, який включає природні і створені людиною туристичні ресурси, а також транспортну і сервісну інфраструктури;

2) рівень інтелектуальної технології, який пов'язаний 3 цією фізичною інфраструктурою і надає серверні бізнес-рішення і клієнтські програми;

3) рівень даних, який включає сховище даних, відкриті інформаційні центри даних і додатки для інтелектуального аналізу даних;

4) бізнес-рівень, що впроваджує інновації на основі доступних технологій i відповідних джерел даних;

5) рівень досвіду, на якому використовуються отримані в результаті технології і розширені дані. 
Отже, «розумний» туризм - тенденція, що набирає обертів та, завдяки якій і громадяни і туристи отримують можливість взаємодіяти 3 більш зручним, безпечним та цікавим середовищем проживання. «Розумне» середовище індивідуалізує одержані туристом враження і збагачує їх, дозволяє йому діяти без посередництва професійних туроператорів. Для бізнесу, «розумні» дестинації відкривають раніше недосяжні можливості вдосконалення пропонованих продуктів і послуг, відпрацювання нових бізнес-моделей. «Розумні» дестинації стають новими ланцюжками доданої вартості за рахунок революційного об'єднання інформаційно-комунікаційних технологій 2.0, зусиль дизайнерів і архітекторів, міських планувальників і представників традиційного туристичного бізнесу.

Нові способи комерціалізації інформаційно-комунікаційних технологій в процесі їх впровадження на ринку туристичних послуг вимагають більш уважного вивчення як 3 боку можливостей, що відкриваються IКТ, так і з боку напрямків розвитку туристичного бізнесу. Інновації виникають під впливом швидких змін на ринку туризму і удосконалення технологій «розумного» мобільного зв'язку.

У той же час необхідно враховувати, що і розвиток ІКТ, і розвиток ринку туристичних послуг в умовах ринкової економіки стимулюється двояко: рухом попиту на відповідні послуги в обох областях і трансформаціями впровадження нових товарів і послуг. Схему інноваційного розвитку «розумної» дестинації можна, таким чином, представити у вигляді квадрата детермінант, що визначають ії розвиток. Звісно ж, що такими детермінантами виступають взаємопов'язані фактори попиту і пропозиції в двох секторах економіки - ІКТ сектора і туризму (рис. 1):

\begin{tabular}{|l|c|c|}
\cline { 2 - 3 } \multicolumn{1}{c|}{} & Попит (Пт) & Пропозиція (П) \\
\hline Попит (Пт) & II сектор & III сектор \\
& ППт & ПтПm \\
\hline Пропозиція & I сектор & IV сектор \\
(П) & ПП & $\Pi m \Pi$ \\
\hline
\end{tabular}

Рисунок 1. Детермінанти інноваційного розвитку «розумної» дестинації [9]

3 рисунку можна спостерігати, що розвиток «розумної дестинації» може відбуватися під впливом пропозиції нових технологій, що підкріплюється пропозицією нових туристичних послуг (сектор I), або навпаки, з огляду на активізацію попиту на нові послуги, можливість надання яких забезпечується через впровадження нових технологій (сектор III). Як пропозиція, так і попит в обох секторах виявляються схильними до ефекту синергії між собою. Інша ситуація, - коли передові інформаційнокомунікаційні технології вже впроваджені, а ринок туристичних послуг їх ще поки не освоїв, туристичний бізнес починає програвати в змаганні іншим дестинаціям. Тиск попиту на туристичні послуги нового типу зростає (сектор IV). Нарешті, можлива ситуація, коли рівень розвитку туристичних послуг та готовності до впровадження нових форм бізнесу вже досить високий, в той час як пропозиція нових IКТ, наприклад, широкосмугового Інтернету Wi-Fi, з певних причин в цій дестинації відстає (сектор II). В даному випадку зазначений вище синергійний ефект буде працювати за допомогою стимуляції попиту на нові технології та в напрямку вирівнювання невідповідності між пропозицією досить розвинутих туристичних послуг i оптимальним рівнем їх інформаційно-комунікаційного забезпечення.

Можна виділити соціальні і економічні вигоди від «перетікання» елементів «розумного» міста в туризм. До соціальних вигод можна віднести наступні. 
1. За допомогою даних технологій вирішується кілька основних проблем туриста: підвищується обізнаність про різні аспекти життя в даній дестинації, а також економлять час на бронювання необхідних послуг. Все це підвищує загальне враження від поїздки і веде до збільшення зацікавленості туриста і задоволеності.

2. Інтегровані технології дозволяють налагодити співпрацю між різними галузями, що веде до нових видів взаємодії, отже, до поліпшення якості туристичних послуг;

3. Поліпшення якості послуг туристичних послуг стимулює зростання і розвиток сфери туризму і веде до більшої задоволеності від поїздки і розширенню «клієнтської бази» туризму;

4. Покращується імідж міста в цілому, як туристичної дестинації.

До економічних вигод розвитку міського простору відносяться:

- створення нових робочих місць і збільшення податкових надходжень, що веде до поліпшення якості життя населення;

- поліпшення умов i якості життя місцевого населення стимулюється регіональний економічний розвиток і формується сприятливий імідж;

- оновлений імідж формує бренд місту, що привертає приватний капітал і також веде до економічного розвитку.

Можна зробити висновок про те, що розвиток технологій «розумного міста» закономірно призведе до виділення сектора «розумний туризм».

Таким чином, назріла необхідність розробки моделі «розумний» туризм«розумний турист», яка сприятиме створенню туристичних інформаційних інфраструктур, наданню туристам послуг високої якості і допомоги в створенні туристичних брендів, здатних зайняти лідируючі позиції в країні і світі. За рахунок створення універсальної туристичної користувальницької системи всі місцеві туристичні ресурси можуть використовуватися туристами спільно. Для зручності туристів, а також з метою централізації збору і обробки туристичної інформації мають застосовуватися розумні карти, однорічні карти і двовимірні коди. Цифрова платформа туристичного обслуговування «розумний турист» повинна бути частиною «розумного» міста, а її послуги розраховані як на мешканців міста, так і на гостей. Сервіс «активний городянин» дасть можливість поліпшити якість життя громадян і якість управління містом через активне залучення мешканців.

Висновки та перспективи подальших досліджень. У даній роботі наводяться результати концептуального аналізу поняття «розумної» туристичної дестинації і дається огляд основних складових іiі практичного втілення. Ідентифіковано основні закономірності запропонованого впровадження нових інформаційно-комунікаційних технологій розвитку сучасних туристичних центрів. Проаналізовано принципи та практики взаємопов'язаних етапів і стратегій цього розвитку - програм «розумного міста» і бізнес-стратегії «розумної дестинації». Розумні міста відкривають шлях до розвитку нових послуг в сфері туризму. «Розумність» туристичної дестинації визначається не тільки іï інформаційно-комунікаційними інноваціями, а й технологіями, які дозволяють покращити людську мобільність, а владі формувати політику, засновану на знаннях і передових послугах для гостей. Імідж дестинації з розвитком «розумного» туризму представляє собою складну соціальну конструкцію, в якій задіяні, органи місцевого врядування, бізнес, мешканці та туристи.

Обгрунтовано принципові відмінності «розумного» туризму від туризму традиційного. Суть цих відмінностей можна звести до суто кількісного ефекту раціоналізації і економії коштів, одержуваних від експлуатації нових технологій. 
Йдеться про збагачення і індивідуалізацію туристичного досвіду. Завдяки виведенню придбаного в місцях дестинації досвіду на якісно новий щабель. Драйвери інноваційності туристичної дестинації можуть надходити як з боку пропозиції нових технологій ініціативними підприємцями, так і з боку активізації попиту на нові послуги 3 боку клієнтів. Іншими словами, якщо дестинація з тих чи інших причин відстає від світових лідерів галузі, то вона програє в міжнародному змаганні тим туристичним центрам, де нові технології вже впроваджені. Якщо технологічні інновації не активувати, відставання може стати незворотним.

«Розумний» туризм вже тут і визначає перспективи розвитку галузі. Однак дослідження цього складного феномена перебувають в розвитку. Порівняльне i комплексне вивчення досвіду «розумних» дестинацій безсумнівно залишиться одним 3 основних напрямків цих досліджень. Також необхідні індикатори «розумності» для регіонального рівня, щоб можна було належним чином оцінити зусилля в сфері розвитку. Крім того, існує велика потреба в тематичних дослідженнях на регіональному рівні, щоб проілюструвати і порівняти можливості та проблеми, які виникають на практиці при застосуванні принципів «розумного» туризму в регіонах. Прийняття регіональних перспектив для розвитку і досліджень розумного туризму має велике значення.

\section{СПИСОК ВИКОРИСТАНИХДЖЕРЕЛ}

1. New Platform Tourism Services (or the so-called Sharing Economy) - Understand, Rethink and Adapt. UNWTO, 2017.- URL: https://www.e-unwto.org/doi/book/ $10.18111 / 9789284419081$

2. Smart cities of the world. Energy, Transport and Lighting 2016-2021. UK, Juniper Research Ltd. - URL: https://www.juniperresearch.com/researchstore

3. Туник О. М. Смарт-туризм: система взаємовідносин в дестинації. Міжнародний туристичний бізнес : зб. наук. ст. студ. денної і заочної форми навч. / відп. ред. А. А. Мазаракі. Київ : Київ. нац. торг.- екон. ун-т, 2017. С. 329-335

4. Савіна Г. Г., Яковенко О. В. Управління клієнтською базою туристичного підприємства із застосуванням інтернет-ресурсів: економічний аспект. Науковий вісник Ужгородського національного університету. Випуск 25. Частина 2. 2019. С. 107-110

5. Descubre la gastronomía Alicantina y vive experiencias únicas con alicante SMART destination. - URL: http://alicantesmartdestination.com

6. Xiang, Z., Tussyadiah, I., and Buhalis, D. (2015): «Special Issue: Smart destinations», Journal of Destination Marketing \& Management, 4(3), 143-201.

7. Lamsfus C., Martín D., Alzua-Sorzabal A., Torres-Manzanera E. (2015) Smart Tourism Destinations: An Extended Conception of Smart Cities Focusing on Human Mobility. In: Tussyadiah I., Inversini A. (eds) Information and Communication Technologies in Tourism 2015. Springer, Cham pp.363-375

8. Gretzel, U., Ham, J., and Koo, C. (2018): «Creating the City Destination of the Future - The Case of Smart Seoul», in Wang, Y., Shakeela, A., Kwek, A., and KhooLattimore, C. (eds.), Managing Asian Destinations, Cham, Switzerland, Springer, 199-214.

9. Hwang, J., Park, H.-Y., \& Hunter, W. C. (2015). Constructivism in Smart Tourism Research : Seoul Destination Image. Asia Pacific Journal of Information Systems, 25(1), 163178. https://doi.org/10.14329/apjis.2015.25.1.163

10. Koo, C., Shin, S., Kim, K., Kim, C., and Chung, N. (2013): «Smart Tourism of the Korea: A Case Study», PACIS 2013. Accessed online (July 1, 2018) at: http://www.pacisnet.org/proceeding. php?paperyear=2013. 
11. D., Li, X., and Li, Y. (2013): «China's "smart tourism destination" initiative: A taste of the service-dominant logic», Journal of Destination Marketing \& Management, 2(2), 59-61.

\section{REFERENCES}

1. New Platform Tourism Services (or the so-called Sharing Economy) (2017) Understand, Rethink and Adapt. UNWTO.- URL: https://www.e-unwto.org/doi/book/ $10.18111 / 9789284419081$

2. Smart cities of the world. Energy, Transport and Lighting 2016-2021. UK, Juniper Research Ltd. - URL: https://www.juniperresearch.com/researchstore

3. Tunik O. M. Smart-turizm: sistema vza€movidnosin v destinaciï (Smart tourism: the system of relationships in the destination) (2017). Mizhnarodnij turistichnij biznes : zb. nauk. st. stud. dennoï i zaochnoï formi navch. / vidp. red. A. A. Mazaraki. Kiïv : Kï̈v. nac. torg.ekon. un-t. pp. 329-335

4. Savina H. H., Yakovenko O. V. (2019). Upravlinnya kliyent-skoyu bazoyu turystychnoho pidpryyemstva iz zastosuvannyam internet-resursiv: ekonomichnyy aspekt. Naukovyy visnyk Uzhhorodskoho natsionalnoho universytetu. Vypusk 25. Chastyna 2. pp. $107-110$

5. Descubre la gastronomía Alicantina y vive experiencias únicas con alicante SMART destination. - URL: http://alicantesmartdestination.com

6. Xiang, Z., Tussyadiah, I., and Buhalis, D. (2015). «Special Issue: Smart destinations», Journal of Destination Marketing \& Management, 4(3), 143-201.

7. Lamsfus C., Martín D., Alzua-Sorzabal A., Torres-Manzanera E. (2015) Smart Tourism Destinations: An Extended Conception of Smart Cities Focusing on Human Mobility. In: Tussyadiah I., Inversini A. (eds) Information and Communication Technologies in Tourism 2015. Springer, Cham pp.363-375

8. Gretzel, U., Ham, J., and Koo, C. (2018): «Creating the City Destination of the Future - The Case of Smart Seoul», in Wang, Y., Shakeela, A., Kwek, A., and KhooLattimore, C. (eds.), Managing Asian Destinations, Cham, Switzerland, Springer, 199-214.

9. Hwang, J., Park, H.-Y., \& Hunter, W. C. (2015). Constructivism in Smart Tourism Research : Seoul Destination Image. Asia Pacific Journal of Information Systems, 25(1), 163 178. - URL: https://doi.org/10.14329/apjis.2015.25.1.163

10. Koo, C., Shin, S., Kim, K., Kim, C., and Chung, N. (2013): «Smart Tourism of the Korea: A Case Study», PACIS 2013. - URL: http://www.pacisnet.org/proceeding.php?paperyear $=2013$.

11. D., Li, X., and Li, Y. (2013): «China's "smart tourism destination" initiative: A taste of the service-dominant logic», Journal of Destination Marketing \& Management, 2(2), 59-61. 


\section{Корж Н. В.,Онищук Н.В.,}

\section{ФАКТОРЫ ИННОВАЦИОННОГО РАЗВИТИЯ ТУРИСТИЧЕСКИХ}

\section{ДЕСТИНАЦИЙ}

В статье рассматривается понятие «умной» туристической дестинации и анализируются типичные особенности «умной» дестинации и «умного» города. На основе обобщения передового зарубежного опыта рассмотрены технологические основы «умного» туризма. Предлагается оригинальная модель основных факторов инновационного развития туристских дестинаций. Обосновано, что «умный туризм» привносит дополнительные социальные и экономические выгоды, способствует повышению конкурентоспособности высоких технологий в туристической сфере, оптимизирует профессиональную структуру туризма и обогащает эмоциональный капитал туриста. Кроме того, он формирует спрос, регулирует потребление между традиционными и инновационными дополнительными услугами.

Ключевые слова: туризм, знания, эмоциональный капитал, SMART-критерии, умный туризм, умный город.

Korzh N. V., Onyshchuk N. V.,

\section{FACTORS OF INNOVATIVE DEVELOPMENT OF TOURIST DESTINATIONS}

The article discusses the concept of a «smart» tourist destination and analyzes the typical features of a «smart» destination and a «smart» city. Based on the generalization of advanced foreign experience, the technological foundations of «smart» tourism are considered. A model of the main factors of innovative development of tourist destinations is proposed. It is substantiated that «smart tourism» brings additional social and economic benefits, contributes to the competitiveness of high technologies in the tourism sector, optimizes the professional structure of tourism and enriches the emotional capital of the tourist. In addition, it generates demand, regulates consumption between traditional and innovative value-added services. smart city.

Key words: tourism, knowledge, emotional capital, SMART criteria, smart tourism, 